\title{
Molecular detection of northern leatherside chub (Lepidomeda copei) DNA in environmental samples
}

\author{
Joseph C. Dysthe ${ }^{1, *}$, Kellie J. Carim $^{1}$, Thomas W. Franklin ${ }^{1}$, Dave Kikkert ${ }^{2}$, \\ Michael K. Young ${ }^{1}$, Kevin S. McKelvey ${ }^{1}$, and Michael K. Schwartz ${ }^{1}$ \\ ${ }^{1}$ U.S. Forest Service, National Genomics Center for Wildlife and Fish Conservation, \\ Rocky Mountain Research Station, Missoula, MT 59801 \\ ${ }^{2}$ Stantec, Inc., Salt Lake City, UT 84107
}

\begin{abstract}
Aвstract.-The northern leatherside chub (Lepidomeda copei) is a cyprinid fish native to the Snake River, Green River, and Bonneville basins of the western United States. Population declines prompted the development of a multistate conservation agreement and strategy, which emphasized the need to reliably delineate its current distribution and monitor its status. To facilitate species monitoring, we developed a quantitative PCR assay to detect northern leatherside chub DNA in environmental samples. The assay consistently detected northern leatherside chub DNA in concentrations as low as 2 copies per reaction and did not amplify DNA of potentially sympatric fish species. The assay amplified a synthetic DNA template representing 3 congeneric species: White River spinedace (L. albivallis), Virgin spinedace, (L. mollispinis mollispinis), and Big Spring spinedace, (L. m. pratensis); however, none of these are sympatric with northern leatherside chub. Field tests of the assay accurately reproduced expected patterns of species occupancy.

Resumen.-La especie Lepidomeda copei es un pez ciprínido nativo de las cuencas del Río Snake, Río Green y del Lago Bonneville del oeste de los Estados Unidos. La disminución de su población impulsó el desarrollo de un acuerdo de conservación multi-estado, que enfatiza la necesidad de delinear con precisión su distribución actual y de monitorear su estado. Para facilitar el monitoreo de las especies, aplicamos la técnica cuantitativa de Reacción en Cadena de la Polimerasa (PCR, por sus siglas en inglés) que permitió detectar ADN de L. copei en muestras ambientales. La técnica detectó de manera consistente ADN de $L$. copei en concentraciones menores a 2 copias por reacción, sin amplificar ADN de otras especies de peces potencialmente simpátricas. La técnica amplificó un templado de ADN sintético que representa tres especies congenéres: L. albivallis, L. mollispinis mollispinis, y L. m. pratensis. Sin embargo, ninguna de estas especies es simpátrica con L. copei. Los muestreos de campo reprodujeron con precisión los patrones previstos en cuanto a la ocupación de las especies.
\end{abstract}

Fishes of the genus Lepidomeda (family Cyprinidae) are patchily distributed throughout warm- and cold-desert streams of the Bonneville, Colorado River, and Snake River basins (UDWR 2009, Blakney et al. 2014). This group has been the subject of some taxonomic revision. Until 2004, the leatherside chub (Snyderichthys copei or Gila copei; Johnson et al. 2004) was considered a broadly distributed taxon of the intermountain western United States. Considering genetic, morphological, and ecological evidence, however, Johnson et al. (2004) split this taxon into 2 species and placed them in the genus Lepidomeda: the southern leatherside chub (L. aliciae) in the southern Bonneville basin and the northern leatherside chub (L. copei) in the northern
Bonneville and Snake River basins. They also concluded that northern leatherside chub is not the sister taxon to southern leatherside chub, but is more closely related to Virgin spinedace (L. mollispinis) and White River spinedace (L. albivallis) (Johnson et al. 2004).

Due to this taxonomic revision and the understanding of the northern leatherside's taxonomic uniqueness, there has been greater interest in the evaluation of its current distribution. While some populations that were regarded as introduced (UDWR 2009) were actually likely to be indigenous (Blakney et al. 2014), suggesting a wider range than previously thought, there is a broad consensus that the northern leatherside chub has declined across its range and has been extirpated from

*Corresponding author: jdysthe@fs.fed.us 
several basins (Belk and Johnson 2006, UDWR 2009). To mitigate further range contractions, this taxon was petitioned for listing under the U.S. Endangered Species Act (USFWS 2011) and was designated as a species of conservation concern throughout its range (UDWR 2009). Conservation efforts have emphasized the need to assess the distribution of northern leatherside chub (Blakney et al. 2014, Schultz et al. 2016), but its patchy occurrence and low relative abundance (UDWR 2009, Dauwalter et al. 2014) have sometimes made this task challenging. Thus, developing a rapid and reliable method for assessing presence and distribution would be useful for evaluating species status and prioritizing conservation efforts for this species.

Environmental DNA (eDNA) sampling has proven to be an efficient and reliable method for delineating distributions of rare species (McKelvey et al. 2016) and detecting sensitive species (Thomsen et al. 2012, Sigsgaard et al. 2015, Spear et al. 2015) or species difficult to sample using traditional approaches (Taberlet et al. 2012). Furthermore, analysis of eDNA via quantitative PCR (qPCR) is more sensitive and effective in detecting low DNA concentrations than traditional PCR methods (Wilcox et al. 2013, 2016). Accordingly, we developed a qPCR assay for northern leatherside chub for eDNA-based detection throughout its range.

To develop an eDNA assay for northern leatherside chub, we examined 54 GenBank sequences of the cytochrome $b$ (cytb) mitochondrial region of northern leatherside chub and 14 sympatric or closely related nontarget species (Table 1). We screened these sequences in MEGA 6 (Tamura et al. 2013) and identified candidate primer sites that would amplify an 80-nucleotide fragment unique to northern leatherside chub (Table 2). Within this fragment, we designed a FAMlabeled, minor-groove-binding, nonfluorescent quencher (MGB-NFQ) probe (Table 2). We maximized within-primer and within-probe nucleotide mismatches with nontarget species to avoid instances of primer competition and cross-amplification of the probe (Wilcox et al. 2013). We adjusted primer and probe lengths to optimize annealing temperatures in Primer Express 3.0.1 (Life Technologies), and screened them for secondary structures using IDT OligoAnalyzer (https://www.idtdna.com/calc/ analyzer). Using the NCBI nucleotide BLAST tool, we further examined the specificity of each component of the assay in silico to determine potential sources of nontarget detection.

We then compared the candidate assay with all northern leatherside chub cytb sequences $(n=47)$ available on GenBank (AF270885-AF270893, Johnson and Jordan 2000; AF452086-AF452087, Dowling et al. 2002; AY825431-AY825445, Johnson et al. 2004; JX443059, Schonhuth et al. 2012; and KJ175008-KJ175027, Blakney et al. 2014). These sequences were obtained from fish collected in 24 streams throughout the Bear River, Green River, and Snake River watersheds in Idaho, Nevada, Utah, and Wyoming. We found that one of the 47 sequences (accession: KJ175010; Blakney et al. 2014), which was not evaluated in the initial in silico step, contained a single nucleotide polymorphism (SNP) in which guanine replaced adenine 10 bases from the $3^{\prime}$ end of the probe. This fish originated in Muddy Creek within the Bear River basin in Wyoming, and was the only fish with this SNP in 225 sequences examined by Blakney et al. (2014), which included other northern leatherside chubs collected from Muddy Creek (Ernest Keeley, Idaho State University, personal communication). To ensure detection of this rare haplotype, we developed an additional probe incorporating this SNP; the assay is a mixture of both probes (Table 2).

We tested the specificity of the assay in vitro using a StepOne Plus Real-time PCR Instrument (Life Technologies) in $15-\mu \mathrm{L}$ reactions containing $7.5 \mu \mathrm{L}$ of Environmental Master Mix 2.0 (Life Technologies), $900 \mathrm{nM}$ each of forward and reverse primer, $125 \mathrm{nM}$ of each probe, $4 \mu \mathrm{L}$ DNA template $(\sim 0.4 \mathrm{ng})$, and the remaining volume with PCR-grade water. Thermocycler conditions were $95^{\circ} \mathrm{C}$ for 10 min followed by 45 cycles of denaturation at $95^{\circ} \mathrm{C}$ for $15 \mathrm{~s}$ and annealing and extension at $60{ }^{\circ} \mathrm{C}$ for $1 \mathrm{~min}$. We screened DNA extracted from 17 northern leatherside chub tissues from 3 locations and from 22 additional species (Table 3). DNA used in this study was obtained from archival samples, or from fin clips collected from fish that were immediately released at the point of capture. Fin clips were stored in $\geq 95 \%$ ethanol until DNA was extracted using the DNeasy Tissue and Blood Kit (Qiagen, Inc) according to the manufacturer's instructions. 


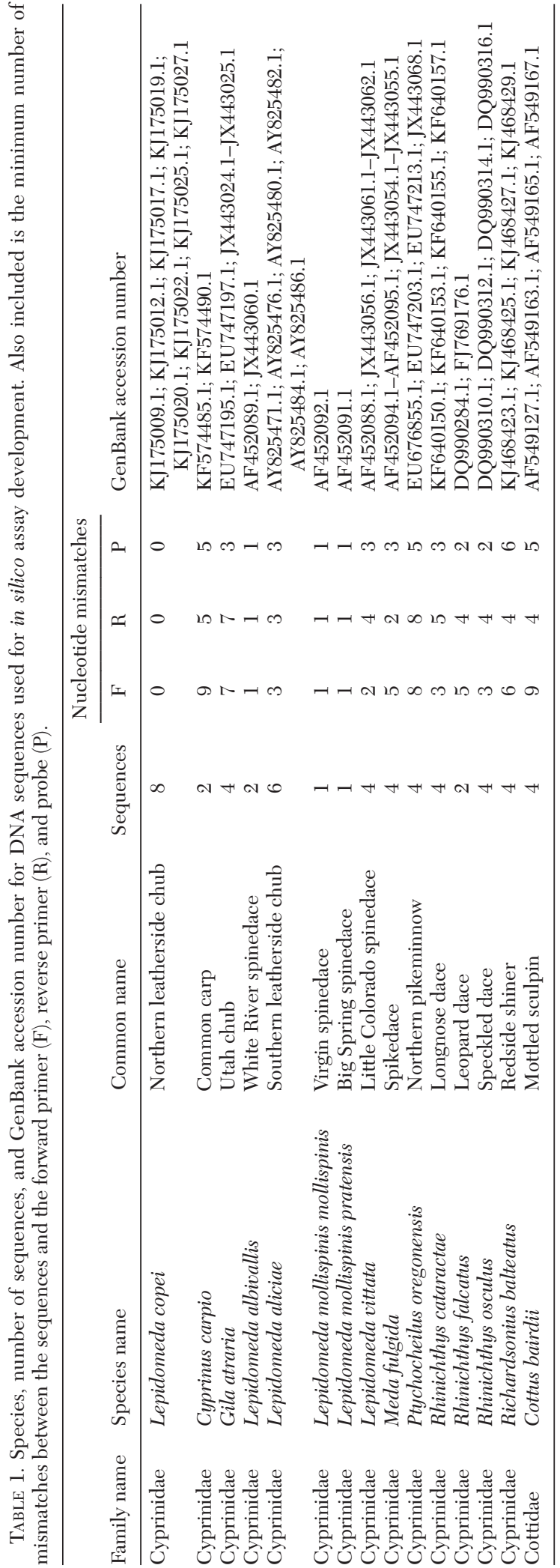


We were not able to obtain tissue from several important species, specifically the rare haplotype of northern leatherside chub and 3 congeneric taxa of spinedace (White River spinedace L. albivallis; Virgin spinedace, L. mollispinis mollispinis; and Big Spring spinedace, $L . m$. pratensis). To test the ability of the assay to detect these specimens, we developed and screened 2 synthetic plasmid DNA fragments encompassing the assay's amplicon in the cytb region (Carim et al. 2016a). The plasmids were synthesized by inserting a 90-nucleotide fragment containing the DNA sequence of the rare haplotype of northern leatherside chub (accession: KJ175010.1) and of the White River spinedace (accession: AF452089.1), respectively, into ampicillin vectors containing PvuI cut sites (pIDTSMART-AMP; Integrated DNA Technologies). The White River spinedace sequence was used to represent the Big Spring (accession: AF452091.1) and Virgin spinedaces (accession: AF452092.1) as all 3 species differed by only a single base across the 90nucleotide fragment. Furthermore, all 3 spinedace sequences contained mismatches in 3 locations with the assay; 2 bases from the $3^{\prime}$ end of the forward primer, 15 bases from the $3^{\prime}$ end of the reverse primer, and 5 bases from the 3 ' end of the probe. The sequence for each plasmid construct was verified on both strands via Sanger sequencing by the supplier, Integrated DNA Technologies, using M13 primers (Integrated DNA Technologies). We linearized the plasmids with PvuI (Invitrogen catalog \# 25420-118) according to the manufacturer's protocol, purified the products using the GeneJET PCR Purification Kit (ThermoFisher Scientific), quantified DNA concentrations with a Qubit 2.0 fluorometer (ThermoFisher Scientific), and diluted samples to $0.1 \mathrm{ng} / \mu \mathrm{L}$ in sterile $\mathrm{TE}$ prior to analysis.

We optimized primer concentrations by varying the amount of both primers between $100,300,600$, and $900 \mathrm{nM}$ for a total of 16 different combinations (Wilcox et al. 2015). For subsequent analyses, we selected the lowest primer concentrations that displayed a high end-point fluorescence relative to the highest (900 $\mathrm{nM}$ for each primer) concentrations tested and that resulted in the lowest $\mathrm{C}_{\mathrm{t}}$ value (the earliest cycle at which the amplification curve crossed the threshold). Using the 
TABLE 3. Species used for in vitro testing of the northern leatherside chub eDNA assay. For samples of the northern leatherside chub, origin refers to the Idaho waterbody where the samples were collected. For samples of all other species, origin is listed as U.S. state, Canadian province, or synthetic plasmid.

\begin{tabular}{|c|c|c|c|c|}
\hline Family name & Species name & Common name & Sample size & Origin \\
\hline Cyprinidae & Lepidomeda copei & Northern leatherside chub & $\begin{array}{r}4 \\
2 \\
11\end{array}$ & $\begin{array}{c}\text { Goose Creek, ID } \\
\text { Squaw Creek, ID } \\
\text { Tin Cup Creek, ID }\end{array}$ \\
\hline Cyprinidae & Agosia chrysogaster & Longfin dace & 1 & NM \\
\hline Cyprinidae & Cyprinella lutrensis & Redside shiner & 1 & UT \\
\hline Cyprinidae & Cyprinus carpio & Common carp & 1 & MT \\
\hline Cyprinidae & Gila atraria & Utah chub & 1 & ID \\
\hline Cyprinidae & Hybognathus argyritis & Western silvery minnow & 1 & MT \\
\hline Cyprinidae & Lepidomeda albivallis & White River spinedace & 1 & Synthetic plasmid \\
\hline Cyprinidae & Lepidomeda aliciae & Southern leatherside chub & 2 & UT \\
\hline Cyprinidae & Macrhybopsis gelida & Sturgeon chub & 1 & MT \\
\hline Cyprinidae & Macrhybopsis meeki & Sicklefin chub & 1 & MT \\
\hline Cyprinidae & Meda fulgida & Spikedace & 2 & $\mathrm{AZ}, \mathrm{NM}$ \\
\hline Cyprinidae & Pimephales promelas & Fathead minnow & 1 & $\mathrm{NM}$ \\
\hline Cyprinidae & Platygobio gracilis & Flathead chub & 1 & MT \\
\hline Cyprinidae & Ptychocheilus lucius & Colorado pikeminnow & 1 & WY \\
\hline Cyprinidae & Rhinichthys cataractae & Longnose dace & 2 & MT, UT \\
\hline Cyprinidae & Rhinichthys cobitis & Loach minnow & 1 & $\mathrm{NM}$ \\
\hline Cyprinidae & Rhinichthys osculus & Speckled dace & 4 & AZ, NM, UT \\
\hline Catostomidae & Catostomus catostomus & Longnose sucker & 1 & MT \\
\hline Ictaluridae & Ictalurus punctatus & Channel catfish & 1 & MT \\
\hline Salmonidae & Oncorhynchus clarkii bouvieri & Yellowstone cutthroat trout & 1 & ID \\
\hline Salmonidae & Oncorhynchus clarkii utah & Bonneville cutthroat trout & 1 & ID \\
\hline Salmonidae & Oncorhynchus mykiss & Rainbow trout & 1 & ID \\
\hline Salmonidae & Salmo trutta & Brown trout & 1 & $\mathrm{CO}$ \\
\hline Salmonidae & Salvelinus fontinalis & Brook trout & 1 & Quebec \\
\hline
\end{tabular}

optimal concentrations of $300 \mathrm{nM}$ of forward primer and $900 \mathrm{nM}$ of reverse primer and the same PCR recipe and thermal profile above, we tested assay sensitivity by analyzing separate 7-level standard curves created from target qPCR product and from the linearized synthetic plasmid DNA of the rare haplotype. The qPCR product and linear plasmid DNA were purified using PureLink ${ }^{\mathrm{TM}}$ PCR Micro Kit (Invitrogen), quantified on a Qubit 2.0 fluorometer, and serially diluted in sterile TE to $31,250,6250,1250,250,50,10$, and 2 copies per $4 \mu \mathrm{L}$. Both standard curves were analyzed across 6 replicates at each level on the same 96-well plate. In addition, because synthetic plasmid DNA of the White River spinedace was detected with the assay, we created and analyzed a 7-level standard curve using the methods described above.

Finally, we validated the assay in vivo by screening eDNA samples collected from 4 streams in the western United States with known patterns of occupancy by northern leatherside chub (Table 4). In 2 of the streams where northern leatherside chubs were initially absent (Jensen and Trout Creeks), eDNA samples were collected for a separate study at known distances downstream of caged northern leatherside chubs. Northern leatherside chubs were placed into each stream in a cage (similar to Jane et al. 2015), and eDNA samples were collected before the cages were placed into the streams. Then, 2 days later eDNA samples were taken at 50, 100, 200, $300,400,500$, and $1000 \mathrm{~m}$ downstream in each creek. This sampling design was replicated in 2 other reaches of each creek on different days using different specimens. Because the purpose, in this context, was to affirm the ability of the assay to detect northern leatherside when eDNA was present, we selected samples collected at 100,200,300, and $400 \mathrm{~m}$ from one reach of each creek. Here, 7 northern leatherside chubs (84 to $118 \mathrm{~mm}$ in length and weighing 5.5 to $15 \mathrm{~g}$ in Jensen Creek; 95 to $112 \mathrm{~mm}$ in length and weighing 8 to $12 \mathrm{~g}$ in Trout Creek) were placed into each stream in a cage before eDNA samples were collected. Previous studies using similar caged fish experiments detected eDNA perfectly at distances up to $250 \mathrm{~m}$ downstream from the cages (Jane et al. 2015) including during a flood event, indicating that $250 \mathrm{~m}$ was a conservative detection distance. However, the ability 
TABLE 4. Collection information for eDNA samples used for in vivo validation of the northern leatherside chub eDNA assay.

\begin{tabular}{|c|c|c|c|c|}
\hline Waterbody (state) & Latitude & Longitude & Expected $^{\mathrm{a}}$ & Dectected $^{a}$ \\
\hline \multirow[t]{6}{*}{$\overline{\text { Jenson Creek (ID) }}$} & 43.184053 & -111.165938 & $\mathrm{~N}^{\mathrm{b}}$ & $\mathrm{N}$ \\
\hline & 43.176676 & -111.153279 & $\mathrm{~N}^{\mathrm{b}}$ & $\mathrm{N}$ \\
\hline & 43.200062 & -111.190858 & $\mathrm{Y}$ & $\mathrm{Y}$ \\
\hline & 43.199314 & -111.190092 & Y & $\mathrm{Y}$ \\
\hline & 43.198735 & -111.189428 & $\mathrm{Y}$ & $\mathrm{Y}$ \\
\hline & 43.198109 & -111.188915 & $\mathrm{Y}$ & $\mathrm{Y}$ \\
\hline \multirow[t]{5}{*}{ Trout Creek (ID) } & 43.158117 & -111.071187 & $\mathrm{~N}^{\mathrm{b}}$ & $\mathrm{N}$ \\
\hline & 43.142916 & -111.080279 & $\mathrm{Y}$ & $\mathrm{Y}$ \\
\hline & 43.143605 & -111.079783 & $\mathrm{Y}$ & $\mathrm{Y}$ \\
\hline & 43.144306 & -111.079307 & $\mathrm{Y}$ & $\mathrm{Y}$ \\
\hline & 43.144902 & -111.078632 & $\mathrm{Y}$ & $\mathrm{Y}$ \\
\hline Rattlesnake Creek (MT) & 46.945720 & -113.945220 & $\mathrm{~N}$ & $\mathrm{~N}$ \\
\hline Tincup Creek (ID) & 42.980710 & -111.281300 & $\mathrm{Y}$ & $\mathrm{Y}$ \\
\hline
\end{tabular}

aN (no) and Y (yes) refer to occupancy of northern leatherside chub based on traditional surveys and eDNA-based detection.

bSamples were taken prior to placement of northern leatherside chub into the stream.

to detect eDNA at greater downstream distances is unknown. eDNA samples were also collected from 2 other streams; one where northern leatherside chub has been observed during historical surveys (Tincup Creek; Table 4 ), and one where northern leatherside chub has never been observed (Rattlesnake Creek; Table 4). The eDNA samples were collected by filtering $5 \mathrm{~L}$ of water using methods outlined in Carim et al. (2016c). DNA was extracted from the filters with the DNeasy Tissue and Blood Kit (Qiagen, Inc) following a modified protocol (Carim et al. 2016b). The extracts were then analyzed using the optimized PCR conditions described above with a TaqMan Exogenous Internal Positive Control $(1.5 \mu \mathrm{L}$ of $10 \mathrm{X}$ IPC assay and $0.15 \mu \mathrm{L}$ of $50 \mathrm{X}$ IPC DNA per reaction; Life Technologies) used in place of some of the water to screen for PCR inhibition. All eDNA analyses were performed across 3 replicates for each eDNA extract and included a PCR no-template control substituting distilled water for DNA template.

The assay detected DNA in vitro from all northern leatherside chub samples, including the plasmid DNA of the rare haplotype. The assay also detected DNA of the plasmid representing the Big Spring, Virgin, and White River spinedaces. The assay did not detect DNA from any of the other nontarget species or in the no-template controls. The standard curve for the common haplotype resulted in an efficiency of $100.8 \%\left(r^{2}=0.996, y\right.$-intercept $=38.8$, slope $=-3.3$ ) and a limit of detection (defined as the lowest concentration with $>95 \%$ amplification success; Bustin et al. 2009) at 2 copies per reaction. The standard curve for the rare haplotype resulted in an efficiency of $102.6 \%\left(r^{2}=0.995, y\right.$-intercept $=38.8$, slope $=-3.3$ ) and a limit of detection at 2 copies per reaction. The DNA of the common and rare haplotypes was detected in all 6 replicates at concentrations averaging 2 copies per reaction. Technically, an assay cannot achieve an efficiency greater than $100 \%$, as that would indicate a more than doubling of the target amplicon during each cycle. However, the reported efficiency value is calculated based on the slope of a linear regression which, due to associated error, can result in an estimated efficiency of $>100 \%$. Assays should have an efficiency as close to $100 \%$ as possible; however, an efficiency between $90 \%$ and $110 \%$ is generally acceptable (Thermofisher Scientific 2016), and the calculated efficiency should be reported even if that value exceeds $100 \%$. The standard curve for the plasmid DNA representing the 3 spinedace taxa was also efficient $\left(98.9 \%, r^{2}=0.984, y\right.$-intercept $=$ 40.2 , slope $=-3.3$, and DNA was detected in 4 of 6 replicates at concentrations averaging 2 copies per reaction. Northern leatherside chub DNA was not detected in any environmental samples taken where the species was expected to be absent. Furthermore, the assay detected northern leatherside DNA in all samples where the species was expected or known to be present, including at 100, 200, 300 , and $400 \mathrm{~m}$ downstream from caged fish in Jensen and Trout Creeks (Table 4).

The ability of the qPCR assay to consistently and reliably detect low concentrations of northern leatherside chub DNA, as indicated by the in vitro standard curve analysis, 
provides support for its application as a sensitive survey tool. Furthermore, the assay did not detect the DNA of potentially sympatric nontarget fish species, or of southern leatherside chub, the taxon from which it was split during previous genetic analyses (Johnson et al. 2004). On the other hand, it did detect a DNA fragment representing 3 congeneric spinedace species: Big Spring, Virgin, and White River spinedaces. This is not surprising given how closely related these species are to the northern leatherside chub (Johnson et al. 2004), resulting in few mismatches between the assay and the spinedace sequences screened (Table 1). However, we do not recommend this eDNA assay for the detection of spinedace because the nucleotide mismatches may lead to reduced detection rates in field applications, especially if PCR inhibitors are present (Jane et al. 2015). Importantly, there are no instances of range overlap between these spinedace species and northern leatherside chub (Jezorek and Connolly 2013), so false positive results (detection of northern leatherside DNA where the species is absent) would be unlikely across the northern leatherside range.

As long as robust eDNA sampling protocols (such as Carim et al. 2016c, McKelvey et al. 2016) are paired with field surveys that address the ecological characteristics influencing the distribution of this species (Dauwalter et al. 2014, Schultz et al. 2016), the assay will be effective at detecting target DNA in low concentrations, as demonstrated by eDNA assays designed for other taxa (Wilcox et al. $2013,2015)$. Results from such surveys could be instrumental in helping biologists and managers target conservation efforts and evaluate the success of northern leatherside reintroduction efforts and other management activities (UDWR 2009). The presence of a rare haplotype from Muddy Creek provides a cautionary note. These rare haplotypes do occur in many species (see Wilcox et al. 2015) and will lead to false negative results if the haplotypes are unknown and fixed within a local population. Therefore, when entering a new area, we suggest either testing the assay by first collecting samples in areas where the target species is known to be present or by sequencing the primer/probe region from locally derived tissue samples prior to relying on assay results for management.

\section{ACKNOWLEDGMENTS}

We thank Lee Mabey (Caribou-Targhee National Forest), Trout Unlimited, and the Bureau of Land Management for collecting tissue samples.

\section{Literature Cited}

BELK, M.C., AND J.B. JoHnSON. 2006. Biological status of leatherside chub: a framework for conservation of western freshwater fishes. American Fisheries Society Symposium 53:67-76.

Blakney, J.R., J.L. Loxterman, and E.R. Keeley. 2014. Range-wide comparisons of northern leatherside chub populations reveal historical and contemporary patterns of genetic variation. Conservation Genetics $15: 757-770$.

Bustin, S.A., V. Benes, J.A. Garson, J. Helleman, J. Huggett, M. Kubista, R. Mueller, T. Nolan, M.W. Pfaffl, G.L. ShIPley, ET AL. 2009. The MIQE guidelines: minimum information for publication of quantitative real-time PCR experiments. Clinical Chemistry $55: 611-622$.

Carim, K.J., K.R. Christianson, K.S. McKelvey, W.M. Pate, D.B. Silver, B.M. Johnson, B.T. Galloway, M.K. Young, AND M.K SCHWARTZ. 2016a. Environmental DNA marker development with sparse biological information: a case study on opossum shrimp (Mysis diluviana). PLOS ONE 11:e0161664.

Carim, K.J., J.C. Dysthe, M.K. Young, K.S. McKelvey, AND M.K. SCHWARTZ. 2016b. An environmental DNA assay for detecting Arctic grayling in the upper Missouri River basin, North America. Conservation Genetics Resources 8:197-199.

Carim, K.J., K.S. McKelvey, M.K. Young, T.M. Wilcox, AND M.K. Schwartz. 2016c. Protocol for collecting eDNA samples from streams. General Technical Report RMRS-GTR-355, U.S. Department of Agriculture, Forest Service, Rocky Mountain Research Station, Fort Collins, CO. 18 pp. http://www.fs.fed .us/rm/pubs/rmrs_gtr355.pdf

Daunalter, D.C., S.J. Wenger, and P. Gardner. 2014. The role of complexity in habitat use and selection by stream fishes in a Snake River basin tributary. Transactions of the American Fisheries Society 143:1177-1187.

Dowling, T.E., C.A. Tibbets, W.L. Minckley, and G.R. Sмiтн. 2002. Evolutionary relationships of the plagopterins (Teleostei: Cyprinidae) from cytochrome $b$ sequences. Copeia 2002:665-678.

Jane, S.F., T.M. Wilcox, K.S. McKelvey, M.K. Young, M.K. SchWartz, W.H. Lowe, B.H. Letcher, AND A.R. Whiteley. 2015. Distance, flow and PCR inhibition: eDNA dynamics in two headwater streams. Molecular Ecology Resources 15:216-227.

Jezorek, I.G., AND P.J. Connolly. 2013. Distribution and movement of Big Spring spinedace (Lepidomeda mollispinis pratensis) in Condor Canyon, Meadow Valley Wash, Nevada. Western North American Naturalist 73:323-336.

Johnson, J.B., T.E. Dowling, And M.C. BelK. 2004. Neglected taxonomy of rare desert fishes: Congruent evidence for two species of leatherside chub. Systematic Biology 53:841-855. 
Johnson, J.B., And S. JoRdan. 2000. Phylogenetic divergence in leatherside chub (Gila copei) inferred from mitochondrial cytochrome $b$ sequences. Molecular Ecology 9:1029-1035.

McKelvey, K.S., M.K. Young, E.L. Knotek, K.J. Carim, T.M. Wilcox, T.M. Padgett-Stewart, and M.K. SCHWARTZ. 2016. Sampling large geographic areas for rare species using environmental DNA: a study of bull trout Salvelinus confluentus occupancy in western Montana. Journal of Fish Biology 88: 1215-1222.

Schonhuth, S., D.K. Shiozawa, T.E. Dowling, and R.L. Mayden. 2012. Molecular systematics of western North American cyprinids (Cypriniformes: Cyprinidae). Zootaxa 3586:281-303.

Schultz, L.D., P.A. Cavalli, H. Sexauer, and D. Zafft. 2016. Habitat and fish assemblage associations and current status of northern leatherside chub Lepidomeda copei in western Wyoming. Western North American Naturalist 76:427-440.

Sigsgaard, E.E., H. Carl, P.R. Moller, and P.F. ThomSEN. 2015. Monitoring the near-extinct European weather loach in Denmark based on environmental DNA from water samples. Biological Conservation 183:46-52.

Spear, S.F., J.D. Groves, L.A. Williams, and L.P. Waits. 2015. Using environmental DNA methods to improve detectability in a hellbender (Cryptobranchus alleganiensis) monitoring program. Biological Conservation 183:38-45.

Taberlet, P., E. Coissac, M. Hajibabaei, and L.H Rieseberg. 2012. Environmental DNA. Molecular Ecology 21:1789-1793.

Tamura, K., D. Peterson, N. Peterson, A. Filipski, and S. KumAR. 2013. MEGA6: molecular evolutionary genetics analysis version 6.0. Molecular Biology and Evolution 30:2725-2729.

ThermoFisher Scientific. 2016. Real-time PCR: understanding $\mathrm{C}_{\mathrm{t}}$. Real-time PCR Application Note. Applied Biosystems, ThermoFisher Scientific, Life Technologies. http://www.thermofisher.com/content/
dam/LifeTech/Documents/PDFs/PG1503-PJ9169 -CO019879-Re-brand-Real-Time-PCR-Understanding -Ct-Value-Americas-FHR.pdf

Thomsen, P.F., J. Kielgast, L.L. Iversen, C. Wiuf, M. Rasmussen, M.T.P. Gilbert, L. Orlando, and E. WiLlerslev. 2012. Monitoring endangered freshwater biodiversity using environmental DNA. Molecular Ecology 21:2565-2573.

[USFWS] United States Fish and Wildlife Service. 2011. 12-month finding on a petition to list northern leatherside chub as endangered or threatened. Federal Register 76:63444-63478.

[UDWR] UTAH Division of Wildlife Resources. 2009. Rangewide conservation agreement and strategy for northern leatherside (Lepidomeda copei). Utah Department of Natural Resources, Division of Wildlife Resources - Native Aquatic Species. Salt Lake City, UT. Publication no. 09-11.

Wilcox, T.M., K.J. Carim, K.S. McKelvey, M.K. Young, AND M.K. SChWARTZ. 2015. The dual challenges of generality and specificity with developing environmental DNA markers for species and subspecies of Oncorhynchus. PLOS ONE 10(11):e0142008. https:// doi.org/10.1371/journal.pone.0142008

Wilcox, T.M., K.S. McKelvey, M.K. Young, S.F. Jane, W.H. Lowe, A.R. Whiteley, and M.K. Schwartz. 2013. Robust detection of rare species using environmental DNA: the importance of primer specificity. PLOS ONE 8(3):e59520. https://doi.org/10 .1371 journal.pone.0059520.

Wilcox, T.M., K.S. McKelvey, M.K. Young, A.J. SepulveDa, B.B. Shepard, S.F. Jane, A.R. Whiteley, W.H. LOWE, AND M.K. SChWARTZ. 2016. Understanding environmental DNA detection probabilities: a case study using a stream-dwelling char Salvelinus fontinalis. Biological Conservation 194:209-216.

Received 5 October 2017

Revised 25 January 2018

Accepted 29 January 2018

Published online 4 April 2018 